\title{
CANDIDATURAS AVULSAS NO BRASIL: (Re)leitura a partir da teoria do Estado de Partidos
}

\author{
Denise Goulart Schlickmann ${ }^{1}$ \\ Orides Mezzaroba ${ }^{2}$
}

\section{RESUMO}

Os partidos políticos são estruturas consagradas como indispensáveis à consolidação da Democracia Representativa no Brasil. Apenas mediante filiação partidária o cidadão pode se candidatar e participar da disputa de poder que se consagra nas eleições. Os fundamentos para as candidaturas avulsas, apesar de não encontrarem guarida legislação nacional, estão fortemente alicerçados no direito internacional e a decisão sobre sua licitude, em discussão no Supremo Tribunal Federal, afetará profundamente as estruturas partidárias no Brasil. Este trabalho tem por finalidade fazer a (re)leitura da aplicação da candidatura avulsa no contexto político e jurídico brasileiro a partir da teoria do Estado de Partidos.

Palavras-chave: Partidos Políticos. Democracia Representativa. Elegibilidade. Filiação partidária. Candidaturas avulsas.

${ }^{1}$ Bacharel em Ciências Econômicas, Ciências Contábeis e Direito, pela Universidade Federal de Santa Catarina (UFSC). Pós-graduada em Auditoria Governamental pela FEPESE/UFSC, e em Direito Eleitoral pela UNIVALI. Mestra em Direito pela UFSC. Secretária Geral adjunta da Academia Brasileira de Direito Eleitoral e Político (ABRADEP). Membro do Núcleo de Inteligência da Justiça Eleitoral. Secretária de Controle Interno e Auditoria do TRE/SC. Conferencista na área de direito eleitoral. Autora da obra Financiamento de Campanhas Eleitorais, na nona edição, pela Editora Juruá. Coautora da obra Tratado de Direito Eleitoral, pela Editora Fórum. Coautora da obra Tópicos Avançados de Direito Processual Eleitoral, pela Editora Arraes. Doutoranda no Programa de Pós-Graduação em Direito da Universidade Federal de Santa Catarina.

${ }^{2}$ Professor dos Programas de Mestrado e Doutorado em Direito da UFSC. Coordenador do Programa de Mestrado Profissional em Direito da UFSC. Presidente do Conselho Nacional de Pesquisa e Pós-Graduação em Direito CONPEDI. Pesquisador de Produtividade do CNPq.

Rev. de Teorias da Democracia e Direitos Políticos | e-ISSN: 2525-9660 | Goiânia| v. 5 | n. 1 | p. 41-62 | Jan/Jun. 2019 


\title{
INDIVIDUAL CANDIDATURES IN BRAZIL: (Re) reading from the theory of State Parties
}

\begin{abstract}
Political parties are established structures as indispensable for the Representative Democracy's consolidation in Brazil. Only by means of party affiliation can the citizen apply and participate in the power struggle that is enshrined in the elections. The grounds for individual candidatures, although they do not meet national legislation, are strongly based on international law and the decision on their lawfulness, under discussion in the Federal Supreme Court, will profoundly affect party structures in Brazil. This paper aims at (re) reading the application of the single application in the Brazilian political and juridical context based on the State of Parties theory.
\end{abstract}

Keywords: Political parties. Representative Democracy. Eligibility. Party affiliation. Individual candidacies.

\section{INTRODUÇÃO}

Este artigo tem por objetivo analisar a viabilidade jurídica das candidaturas avulsas no cenário nacional marcado pela prevalência jurídica da filiação partidária como condição de elegibilidade.

Inicialmente, o estudo percorre as relações entre o poder político e a Democracia Representativa, como forma legítima de outorga do poder.

Em seguida examina a teoria prevalente do Estado de Partidos, segundo a qual a existência dos partidos políticos é condição sine qua non para a existência da própria Democracia Representativa, pela realização de eleições cujos candidatos necessariamente precisam estar a eles vinculados.

Rev. de Teorias da Democracia e Direitos Políticos | e-ISSN: 2525-9660 | Goiânia| v. 5 | n. 1 | p. 41-62 | Jan/Jun. 2019 
O estudo examina os principais fundamentos que alicerçam as demandas por candidaturas avulsas, desvinculadas de partidos políticos, buscando identificar as principais questões jurídicas que permeiam essa importante discussão.

Para este estudo foi utilizado o método de abordagem dedutivo e os procedimentos aplicados na investigação envolverão análises doutrinárias, jurisprudenciais e formais.

\section{PODER POLÍTICO E DEMOCRACIA REPRESENTATIVA}

A organização do poder é essencial à conformação do Estado: “[...] a totalidade do poder temporal se reúne para integrar a sua personalidade, fruto de uma vontade coletiva, de uma concepção de unidade formal e ideológica, sem a qual não existe o Estado" (CAVALCANTI, 1969).

Também Kelsen (2001), em sua obra Teoria Pura do Direito, discorre sobre a relação entre Estado e poder para afirmar que, litteris:

Assim como se reconhece o ordenamento coercitivo do direito do Estado como ordenamento e na personificação da unidade desse ordenamento do Estado se reconhece a pessoa, pode-se compreender na eficácia do ordenamento jurídico tudo o que se costuma designar como "poder do estado" ou o Estado como "poder". (KELSEN, 2001, p. 138)

O poder institucional, momentaneamente conferido a um estrato social pelo grupo, precisa de regras também para a determinação de seus limites e, mais que isso, para disciplinar as circunstâncias em que deve ocorrer a sua devolução à Sociedade. Isso porque a garantia do respeito aos direitos da Sociedade como um todo reside, fundamentalmente, no espírito democrático que contraria em essência qualquer estrutura autocrática. Ou seja: o poder político conferido é temporário e, como tal, deve ser devolvido à Sociedade que, através de mecanismos próprios, o confere a um outro estrato social, ao qual caberá administrar os conflitos sociais por um novo período de tempo. A democracia é, nesse aspecto, uma forma de governo, como ensina Kelsen (1993).

A democracia legitima-se pela rotatividade do poder, pela sua renovação periódica. Reside nos fundamentos da democracia a diferença singular entre o poder político e as demais nuances de poder: aquele emana do povo (tal qual prescreveu a Declaração dos Direitos Humanos de 1789) e,

Rev. de Teorias da Democracia e Direitos Políticos | e-ISSN: 2525-9660 | Goiânia| v. 5 | n. 1 | p. 41-62 | Jan/Jun. 2019 
Denise Goulart Schlickmann \& Orides Mezzaroba

como tal, atinge em magnitude o conceito da legitimidade, o que the confere a possibilidade de resolver os problemas sociais e harmonizar a convivência humana.

Inconteste é a afirmação de que nos regimes democráticos o poder político emana da Sociedade e é exercido através de seus representantes, legal e legitimamente constituídos.

No entanto, o exercício do poder exige o estabelecimento de regras que disciplinem a representatividade e, ao mesmo tempo, garantam que a vontade coletiva, entendida esta como a vontade da maioria, seja exercida em plenitude.

Não se pode ignorar, no entanto, que a Sociedade, concebida como um ente único, é composta de indivíduos que pensam e agem diferenciadamente e que, portanto, expressam sua vontade de forma igualmente diversa.

Kelsen (1993) ensina que o povo, constituindo uma massa de indivíduos distintos, não possui vontade uniforme. Antes, é a sua vontade individual real que se manifesta e o governo do povo, de que tanto se diz, é aquele do qual o povo participa direto ou indiretamente, exercido pelas decisões majoritárias colhidas com a sua participação ou pela eleição de um indivíduo que o represente, intermediando eleitorado e eleitor. $\mathrm{E}$ as eleições serão tanto mais democráticas quanto mais se fundamentem no sufrágio universal, igualitário, livre e secreto. Neste sentido, é a participação no governo a característica essencial da democracia.

Ribeiro (2015, p. 16) caracteriza democracia como sendo "[...] sempre um sistema, um método, um processo de composição dos órgãos dirigentes do Estado", trazendo em seu bojo, de forma implícita o conceito de exercício do poder político pelo povo. Não é a democracia, nesse passo, um fim em si mesma. Antes, é o meio pelo qual o povo exerce a soberania e constrói a ordem estatal.

Canotilho (1941, p. 288), por sua vez, ensina que o exercício democrático do poder aponta para o sentido participativo. A participação direta e ativa dos cidadãos é instrumento fundamental da consolidação do sistema democrático. Vale dizer: o Estado Democrático de Direito consagra a dimensão representativa do princípio democrático.

Rev. de Teorias da Democracia e Direitos Políticos | e-ISSN: 2525-9660 | Goiânia| v. 5 | n. 1 | p. 41-62 | Jan/Jun. 2019 
A Sociedade é detentora do poder político puro, sem rótulos e preferências institucionais, características da organização partidária. Por isso, ainda que as diversas concepções sociais se expressem na formação dos partidos políticos, cabe aos indivíduos que compõem a Sociedade (independentemente de filiação partidária) conferir a um ou outro estrato social o poder político, através do voto.

É importante perceber, desta forma, que a Sociedade elege aqueles que, organizados partidariamente, colocam-se à sua disposição para tutelar seus interesses. E, neste caso, não se pode afirmar que o poder político é conferido àqueles que representam de forma mais completa e eficiente a vontade da maioria, mas sim, àqueles que vencem o pleito eleitoral, de acordo com as circunstâncias que o determinam momentaneamente.

O regime democrático é, pois, nas palavras de Cavalcanti (1969, p. 268) “[...] uma organização política que transfere ao povo, não somente o exercício pleno da soberania, mas também imprime certo estado de espírito à consciência coletiva [...]”.

É, nesse sentido, o princípio da representação política que alicerça o regime democrático que operacionaliza a distribuição do poder político.

Em qualquer de suas formas de expressão, que evoluíram ao longo da história, o sistema representativo de governo exige e pressupõe um sistema eleitoral que garanta a legitimidade do ato de votar, expresso na liberdade de manifestação da maioria e na organização de cargos eletivos que viabilizem o exercício do mandato eletivo. Constitui-se este sistema em um mecanismo de controle de que dispõe a Sociedade para a fiscalização do exercício legítimo do poder.

O sistema representativo, como expressão de um ato de delegação de poder, permite estabelecer limites àqueles que exercem, em nome de um grupo, a administração de seus interesses, porquanto estabelece, dentre outros limites, a obrigatoriedade da renovação dos mandatários, que o grupo exerce através dos pleitos eleitorais.

A participação do indivíduo de forma direta ou representativa, na definição de Kelsen (1993), nada mais representa do que o processo de criação e aplicação da ordem social que constitui a comunidade, o critério propriamente dito do sistema político democrático. 
Assim, observa-se que é por ocasião dos pleitos eleitorais que a democracia garante à Sociedade a possibilidade de mudança e, por assim dizer, da avaliação dos mandatários que estiveram no poder. Reside, então, nos pleitos eleitorais e no sistema eleitoral como um todo a responsabilidade de garantir a legitimidade do regime democrático, fundado no Estado Constitucional de Direito sobre o qual leciona Ferrajoli (2015), ao tratar das profundas alterações que este modelo de Estado operou sobre o Estado de Direito, litteris:

Não se tratou apenas da subordinação ao direito do próprio poder legislativo, mas também da subordinação da política a princípios e direitos estipulados nas Constituições como razão de ser de todo o artifício jurídico. Tratou-se, portanto, de uma transformação e de uma integração, além das condições de validade do direito, também das fontes de legitimidade democrática dos sistemas políticos, vinculados e funcionalizados à garantia de tais princípios e direitos (FERRAJOLI, 2015, p. 61).

O denominado sistema de representação das opiniões acentua o pluralismo político da democracia partidária. Ao mesmo tempo que confere a cada voto, independentemente da condição individual de cada eleitor, valor idêntico, dinamiza a vida política e permite, de modo adequado, a representação dos grupos de interesse.

Aí reside o fundamento da representação, segundo ensina novamente Kelsen (1993): a eficácia, como condição de existência do próprio Estado, constituído sob uma ordem jurídica válida e, portanto, eficaz, que torna possível a existência também dos órgãos do Estado.

O regime democrático representativo pressupõe um conjunto de instituições para a disciplina da participação popular no processo político, que, em última instância, garantem o exercício pleno da cidadania.

[...] o termo "representação" pode reivindicar o significado não apenas de representação do Estado, mas, ao mesmo tempo, de representação do povo do Estado, única e exclusivamente se remeter à representação por órgãos eleitos por via democrática. (KELSEN, 1993, p. 151)

O mesmo Kelsen (1993, p. 156) ensina que apenas a ordem jurídica válida é capaz de determinar os representantes e apenas a ordem jurídica relativamente eficaz é ordem válida. Daí a importância da norma, pois "não são os órgãos que são eficazes, mas sim as normas que, em conformidade com uma ordem jurídica válida, eles criam e aplicam”. 
No Brasil, o regime político funda-se no princípio democrático, consagrado constitucionalmente. Consoante prevê a Carta Magna, em seus arts. $1^{\circ}$ e $3^{\circ}$, destina-se a assegurar o exercício dos direitos sociais e individuais, a liberdade, a segurança, o bem-estar, o desenvolvimento, a igualdade e a justiça como valores supremos de uma Sociedade fraterna, livre, justa e solidária, fundada na soberania popular, na cidadania, na dignidade da pessoa humana, nos valores sociais do trabalho e da livre iniciativa, e no pluralismo político.

O sistema eleitoral brasileiro que suporta a estrutura partidária utiliza-se das duas formas conhecidas de representação: o sistema majoritário (para a eleição de senadores e titulares do Poder Executivo) e o sistema proporcional (para a eleição de deputados e vereadores).

É de Silva (1995, p. 138) a lição de que a Democracia Representativa é exercida no Brasil de forma indireta, periódica e formal, por intermédio das instituições eleitorais que objetivam disciplinar e legitimar a escolha dos representantes do povo. A importância da materialização formal do processo democrático e de sua estrutura fundada no Poder Judiciário reside no próprio conceito do ato de votar: eleger significa "[...] expressar preferência entre alternativas, realizar um ato formal de decisão política".

A decisão política do povo é que irá constituir, no processo político, o governo que o representará.

As instituições fundamentais dos direitos políticos são aquelas que constituem o próprio direito eleitoral, ou seja: o direito de sufrágio (de votar e ser votado), os sistemas e os procedimentos eleitorais.

Para Silva (1995, p.337), a igualdade do direito de votar "se manifesta, em seu sentido mais rigoroso, no reconhecer a cada homem, a cada eleitor, um único voto (one man, one vote), pois cada cidadão tem o mesmo peso político e a mesma influência qualquer que seja sua idade, suas qualidades, sua instrução e seu papel na Sociedade”.

O sufrágio, conforme ensina Bonavides (1994, p. 228), “é o poder que se reconhece a certo número de pessoas (o corpo de cidadãos) de participar direta ou indiretamente na soberania, isto é, na gerência da vida pública". Caracteriza a oportunidade da designação de representantes que 
Denise Goulart Schlickmann \& Orides Mezzaroba

exercem o poder e constroem a democracia indireta. Faculta a participação democrática a todos, indistintamente, sem preterir ninguém em função da riqueza, grau de instrução, raça ou sexo.

O direito de sufrágio é exercido através do voto, que o materializa. Através do ato de votar e ser votado o indivíduo exerce uma função social e política, função esta que se origina da soberania popular, fundamento da Democracia Representativa.

Ao mesmo tempo em que é a expressão do direito individual de participação do processo democrático, o sufrágio é também um dever da manifestação desta vontade, sem a qual não há como dar sustentação ao Estado Democrático de Direito.

\section{ESTADO DE PARTIDOS NO CONTEXTO POLÍTICO BRASILEIRO}

São os partidos políticos as instituições que viabilizam o exercício do direito político de votar e ser votado, condição estruturante de todos os direitos políticos e fundamento da Democracia Representativa. Agregam as diferentes correntes de opinião e permitem o fracionamento ideológico da Sociedade que, então, pode fazer a escolha daqueles que a irão representar e administrar seus interesses, representando, segundo ensina Kelsen (1993) instituições mediadoras que contribuem decisivamente para a própria substância da representação.

Os partidos políticos asseguram a autenticidade do sistema representativo, pois organizam e preparam as diversas candidaturas para a disputa que se consagra no pleito eleitoral.

Uma das consequências da função representativa dos partidos é que o exercício do mandato político, que o povo outorga a seus representantes, faz-se por intermédio deles, que, desse modo, estão de permeio entre o povo e o governo, mas não no sentido de simples intermediários entre dois pólos opostos ou alheios entre si, mas como um instrumento por meio do qual o povo governa. Dir-se-ia em tese, ao menos - que o povo participa do poder por meio dos partidos políticos (SILVA, 1995, p. 388).

Na lição de Duverger (1967), a doutrina da representação foi profundamente transformada pelo desenvolvimento dos partidos políticos, que se interpuseram entre eleitor e eleito, nação e parlamento, modificando por completo a natureza das suas relações. O candidato, antes de ser escolhido pelo eleitor, é escolhido pelo partido político. Ainda que se trate de um regime em que

Rev. de Teorias da Democracia e Direitos Políticos | e-ISSN: 2525-9660 | Goiânia| v. 5 | n. 1 | p. 41-62 | Jan/Jun. 2019 
vigora o pluralismo político, embora possam ser muitos os candidatos em quem o eleitor pode votar, todos foram, antes disso, escolhidos pelo próprio partido político a que estão vinculados.

Os partidos dão forma à base das massas que anseiam por expressar a sua opinião no foro representativo da democracia. São eles que cristalizam e elaboram a opinião bruta, lhe dão sustentáculo, atenuando as profundas divergências individuais. Nas palavras de Duverger (1967, p. 413), “é só ele [o partido político] que permite a existência de eleições e de representação política $[\ldots]^{\prime}$.

São os partidos políticos que definem as plataformas eleitorais e ao sintetizar as mais diversas correntes de opinião as difundem, com o objetivo de atrair o maior número possível de eleitores, canalizando as mais distintas opiniões para dar-lhes objetividade, adaptando-as aos interesses dos eleitores. Os partidos políticos conjugam os seus próprios e especiais objetivos com os anseios dos eleitores. Os partidos tanto criam a opinião quanto a representam. (DUVERGER, 1967).

São os partidos políticos que viabilizam o exercício do voto, expressão material do regime democrático representativo e, por fim, do mandato que representará a vontade do eleitor. Sobre o mandato, elucidativa a lição de Aieta (2006, p. 304), ao afirmar que "[...] o mandato perfaz-se como uma construção coletiva de interesses e não simplesmente como uma iniciativa individual."

É a mobilização coletiva que elege, por intermédio da instituição partido político, que reflete a racionalização do poder, situando os partidos políticos no universo da teoria democrática (AIETA, 2006).

Lópes (1982, p. 18) ensina que os partidos políticos não apenas são indispensáveis para o regime democrático representativo como o próprio regime democrático representativo é obra que decorre diretamente das agremiações partidárias.

Ademais, a Constituição Federal já estatui, em seu art. $1^{\circ}$, ao reconhecer o Brasil como Estado Democrático de Direito fundado nos princípios da soberania e do pluralismo político, a representação política como recurso próprio no processo de formação da vontade política. A Carta Magna fixou, desde então e formalmente, a Democracia Representativa partidária no país (MEZZAROBA, 2005). 
Denise Goulart Schlickmann \& Orides Mezzaroba

Também Baracho (1983) afirma serem os partidos políticos o principal meio instrumental para que a Sociedade possa atuar como nação, realizando o próprio objetivo do regime democrático.

A matriz constitutiva do partido político está, desta forma, na própria CRFB, seja pela personificação do pluralismo político que dá forma à democracia de base representativa, já no artigo inaugural da lei máxima, seja pela dicção do art. 17 da mesma Carta, que direta e especificamente autoriza a criação, fusão, incorporação e extinção dos partidos políticos.

Aos partidos políticos foi conferido o monopólio da representação, mediante a escolha dos candidatos que concorrem aos pleitos, uma vez que é condição de elegibilidade a própria filiação partidária (CAMPOS NETO, 2017).

De fato, tanto o nascimento quanto o desenvolvimento dos partidos políticos estão diretamente relacionados ao progressivo aumento da demanda de participação no processo de formação das decisões políticas, pelos mais diversos extratos que compõem a sociedade. E é exatamente por dar voz aos mais diversos extratos sociais que suas funções somente podem ser compreendidas quando examinadas na estrutura econômica, social e política em que estão diretamente inseridos (OPPO, 1998).

É, pois, pelos partidos políticos que se conforma o poder político em si, que se caracteriza pelo uso da força, materializando o poder soberano, "cuja posse distingue, em toda Sociedade organizada, a classe dominante" (BOBBIO, 2000, p. 221).

Não seria possível o avanço da Democracia Representativa, conforme ensina BOBBIO, 2000), sem aumentar-se progressivamente a participação eleitoral até o alcance do sufrágio universal, o que tornou os partidos políticos absolutamente necessários, como titulares da representação política. O partido político acabou por assumir lugar central nos sistemas representativos, representando importante figura intermediária entre o eleitor e o eleito, simplificando e tornando possível o sistema representativo de governo. 
Ainda que os partidos sejam canalizadores de opinião, deve-se considerar que sua composição interna corresponde a apenas parte de uma Sociedade. Sua função, contudo, excede a mera representação de seus membros. Seu papel no jogo político passa a ser mais amplo, de modo que é ele o responsável por traduzir e converter as reivindicações setoriais em projetos políticos globais, de onde se pode asserir que a democracia é o regime exclusivo dos partidos.

$\mathrm{Na}$ verdade, a própria função de intermediar Sociedade e governo teve lugar após a crise de representação do Estado Liberal, sendo o novo modelo o "aperfeiçoamento do sistema de representação política" (MEZZAROBA, 2004, p. 84).

Os partidos políticos, no modelo do Estado de Partidos que se configurou a partir de então, passaram a constituir não apenas intermediadores entre a Sociedade e o Estado, mas entre aquela e seus próprios representantes, eleitos pelo sistema representativo. Tornaram-se elementos importantes a reunir as vontades individuais, concentrá-las no seio interno de suas estruturas e, depois, efetivamente transformá-las em verdadeiras metas programáticas, plataformas políticas direcionadas ao embate político que se dá no processo eleitoral (MEZZAROBA, 2004).

No modelo do Estado de Partidos é no seio das agremiações partidárias que se forma a vontade popular, cuja vontade pessoal dos indivíduos que a compõem passa a constituir uma verdadeira relação com os princípios e programas partidários. O próprio mandato passa a ser partidário.

São eles, os partidos políticos, os "personagens indispensáveis ao debate democrático e têm por finalidade interferir direta ou indiretamente no poder, por influência ou participação efetiva" (MACHADO, 2016).

Peças essenciais ao funcionamento do complexo mecanismo democrático no mundo contemporâneo, os partidos políticos detêm o monopólio do sistema eleitoral, sendo responsáveis, não raras vezes, pela própria definição do perfil do Estado, pois são eles mesmos que acabam por definir o sentido das ações empreendidas pelo Estado. Daí porque se pode afirmar que não existe, efetivamente, representação popular e exercício do poder estatal sem a intermediação partidária (GOMES, 2017). 
Não há como prescindir, hodiernamente, dos partidos políticos para o funcionamento da democracia, daí porque pode-se dizer que o Estado atual é um verdadeiro Estado de Partidos (MEZZAROBA, 2004).

Se nas democracias representativas é pelo voto que se outorga e exerce o poder político, os catalizadores da vontade política que viabilizam o exercício do sufrágio e do próprio poder, que agregam as diferentes correntes de opinião e permitem o fracionamento ideológico da Sociedade que, então, pode fazer a escolha daqueles que a irão representar e administrar seus interesses, são fundantes da própria democracia.

Ao organizar e preparar as diversas candidaturas para as mais diversas disputas eleitorais, os partidos políticos asseguram a autenticidade do sistema representativo. É consequência direta da função representativa dos partidos que o exercício do mandato político, conferido pelo povo a seus representantes, faça-se apenas e exclusivamente por seu intermédio. Fazem os partidos, pois, o verdadeiro elo de ligação entre dois polos - povo e governo - e, mais que isso, não funcionam apenas como elo de ligação, mas como verdadeiro instrumento por meio do qual o povo governa e participa do poder. (SILVA, 1995)

E o sistema representativo está diretamente vinculado ao conceito de Estado Democrático de Direito. Na lição de Gomes (2012), o próprio conceito de Estado Democrático pressupõe tanto a participação dos cidadãos, quanto a incumbência a eles delegada de criar as emanações do Estado e serem delas os principais destinatários. Ou seja, o governo é de fato formado pelos cidadãos e a formação do governo pressupõe a escolha livre pelo voto direto e universal. Em última análise, são os próprios cidadãos que detêm a responsabilidade pela formulação e execução das políticas públicas. E estes se fazem representar no jogo democrático por intermédio do direito de votar e ser votado, o que somente se concretiza pela atuação dos partidos políticos.

No contexto da outorga de poder político, é o procedimento eleitoral o meio pelo qual são desenvolvidos sucessivamente os atos que culminam com a escolha dos eleitos: a 
apresentação das candidaturas, a organização e realização do escrutínio e o contencioso eleitoral.

E nesse processo que culmina com as eleições e a outorga do poder, de base representativa, torna-se evidente que os partidos políticos são atores essenciais, pois é por seu intermédio que as alianças políticas são formadas e são escolhidos aqueles que disputarão as eleições ${ }^{3}$.

A democracia de base representativa pressupõe o procedimento eleitoral, o qual se desenvolve pela sucessão de atos que culminam com a escolha dos eleitos: a apresentação das candidaturas, a organização e realização do escrutínio e o contencioso eleitoral.

A apresentação das candidaturas ao eleitorado compreende os atos de designação dos candidatos em cada partido (que se inicia com as convenções partidárias), seu registro nos órgãos da Justiça Eleitoral Brasileira competentes e a propaganda eleitoral, que busca dar conhecimento à Sociedade do programa de governo proposto.

É a elegibilidade a instituição que define a capacidade eleitoral passiva, ou seja, a capacidade de ser eleito. Estabelece condições, definidas constitucionalmente e regulamentadas em legislação ordinária para que o indivíduo postule o exercício do poder político, ou seja, o mandato.

É condição básica para a elegibilidade o exercício pleno de todos os direitos políticos, além de outras condições específicas delimitadas pela Carta Magna em seu art. 14.

Objetiva o art. 14 da CRFB de 1988 regular a proteção à normalidade e legitimidade das eleições contra, dentre outros aspectos, a influência do poder econômico, instrumentalizando a ação pública com o instituto da inelegibilidade.

Sobre o instituto da inelegibilidade, há que se registrar que não se trata de limitar a cidadania, mas de conferir-lhe a necessária legitimidade de forma a fazer dela instrumento real de promoção política do povo. Seu escopo, seja pela restrição da capacidade política ativa ou passiva,

\footnotetext{
${ }^{3}$ A possibilidade de candidaturas avulsas no Brasil está em discussão no ARE 1.054.490, Relator o Ministro Roberto Barroso, cuja repercussão geral foi reconhecida, mas o mérito ainda não foi apreciado pelo Supremo Tribunal Federal.
}

Rev. de Teorias da Democracia e Direitos Políticos | e-ISSN: 2525-9660 | Goiânia| v. 5 | n. 1 | p. 41-62 | Jan/Jun. 2019 
Denise Goulart Schlickmann \& Orides Mezzaroba

tem por finalidade preservar o funcionamento normal das instituições da influência de pessoas que busquem os mandatos eletivos (LOPES, 1990).

Conforme prescreve a Lei de Inelegibilidade (Lei Complementar 64/1990), constituem fatos geradores da inelegibilidade a inalistabilidade; a indignidade funcional, moral ou administrativa; a participação em funções de governo ou na direção de entidades privadas de atividade econômica ou representativas de classes, capazes de influenciar no processo eleitoral; a irreelegibilidade; a sucessão em qualquer tempo ou substituição, dentro dos seis meses que antecedem o pleito, de titulares do Poder Executivo; e as relações de parentesco com os titulares do Poder Executivo ou de seus substitutos.

Dentre os fatos geradores de inelegibilidade classificados como de indignidade funcional, moral ou administrativa enquadra-se a representação julgada procedente pela Justiça Eleitoral Brasileira, transitada em julgado, em processo de apuração de abuso do poder econômico ou político, para a eleição na qual o candidato concorra ou tenha sido diplomado, bem como para as que se realizarem nos três anos seguintes.

Em momento posterior, já reconhecidas pela Justiça Eleitoral Brasileira as candidaturas, segue-se o escrutínio, que compreende todas as atividades eleitorais que envolvem a votação e a apuração dos votos.

O contencioso eleitoral cabe à Justiça Eleitoral Brasileira e objetiva a eficácia das normas de garantias eleitorais e, em última instância, a legitimidade dos pleitos, daí porque torna-se esta instituição essencial à própria garantia da representatividade democrática e sua atuação determinante para aferir a lisura dos pleitos em todas as suas fases.

\section{CANDIDATURAS AVULSAS E O SISTEMA ELEITORAL BRASILEIRO}

No Brasil, as condições de elegibilidade estão assentadas diretamente na CRFB, art. 14, § $3^{\circ}$, litteris:

Rev. de Teorias da Democracia e Direitos Políticos | e-ISSN: 2525-9660 | Goiânia| v. 5 | n. 1 | p. 41-62 | Jan/Jun. 2019 
Art. 14. A soberania popular será exercida pelo sufrágio universal e pelo voto direto e secreto, com valor igual para todos, [...]

$\S 3^{\circ}$ São condições de elegibilidade, na forma da lei:

I - a nacionalidade brasileira;

II - o pleno exercício dos direitos políticos;

III - o alistamento eleitoral;

IV - o domicílio eleitoral na circunscrição;

V - a filiação partidária;

VI - a idade mínima de:

a) trinta e cinco anos para Presidente e Vice-Presidente da República e Senador;

b) trinta anos para Governador e Vice-Governador de Estado e do Distrito Federal;

c) vinte e um anos para Deputado Federal, Deputado Estadual ou Distrital, Prefeito, Vice-Prefeito e juiz de paz;

d) dezoito anos para Vereador. (grifou-se)

Também a Lei $n^{\circ}$ 9.504/1997, ao estabelecer as regras para as eleições no Brasil, após a reforma eleitoral operada pela Lei $\mathrm{n}^{\circ} 13.488 / 2017$, passou a dispor expressamente a respeito da impossibilidade de candidaturas avulsas:

Art. $11[\ldots]$ [... É vedado o registro de candidatura avulsa, ainda que o requerente tenha filiação partidária.

Observe-se que a legislação nacional está, pois, absolutamente alinhada à tese antes exposta de que a democracia representativa não prescinde dos partidos políticos.

Não obstante a legislação pátria, que expressamente impede o registro de candidaturas avulsas, nas eleições de 2018 houve diversas solicitações de registro de candidaturas dessa natureza, às quais o Tribunal Superior Eleitoral (TSE) negou seguimento pela inexistência de vínculos dos candidatos com partidos políticos. Observe-se o julgado no Agravo Regimental em Petição n ${ }^{\circ}$ 060061420, relator o Ministro Tarcisio Vieira De Carvalho Neto:

ELEIÇÕES 2018. PETIÇÃO. CARGOS DE PRESIDENTE E VICE. CANDIDATURA AVULSA. IMPOSSIBILIDADE. AUSÊNCIA DE PREVISÃO LEGAL. NEGATIVA DE SEGUIMENTO. CERTIDÃO DE TRÂNSITO EM JULGADO. ARQUIVAMENTO.

$[\ldots]$

AGRAVO REGIMENTAL. TEMPESTIVIDADE. ART. $218, \S 4^{\circ}$, DO CPC. JULGAMENTO MONOCRÁTICO. ART. 36, $\$ 6^{\circ}$, DO RITSE. POSSIBILIDADE. DECISÃO AMPARADA NOS ARTS. $14, \S 3^{\circ}, \mathrm{V}, \mathrm{DA}$ CF/88 E $11, \S 14$, DA LEI $n^{\circ}$ 9.504/97 E NA JURISPRUDÊNCIA DESTA CORTE. 
Denise Goulart Schlickmann \& Orides Mezzaroba

\section{ART. 16-A DA LEI No 9.504/97. INAPLICABILIDADE. ARGUMENTOS INAPTOS PARA AFASTAR OS FUNDAMENTOS DO DECISUM AGRAVADO. DESPROVIMENTO.}

\section{[...]}

3. Há tempos está sedimentado neste Tribunal Superior o entendimento segundo o qual, no sistema eleitoral brasileiro vigente, não existe a previsão de candidatura avulsa, de modo que somente os filiados que tiverem sido escolhidos em convenção partidária podem concorrer a cargos eletivos.

4. "O Congresso Nacional, por meio da Lei no 13.488/2017, reafirmou o princípio de vinculação das candidaturas aos partidos políticos, ao acrescentar o $\S 14$ ao art. 11 da Lei $\mathrm{n}^{\circ} 9.504 / 1997$, asseverando que 'é vedado o registro de candidatura avulsa, ainda que o requerente tenha filiação partidária'" (Rec-Rep n ${ }^{\circ} 0600511-$ 13/DF, Rel. Min. Carlos Horbach, DJe de 20.8.2018)

5. Nenhum dos argumentos deduzidos no processo seria capaz de infirmar a conclusão adotada - amparada no atual ordenamento jurídico pátrio (art. $14, \S 3^{\circ}$, V, da Constituição Federal e art. 11, § 14, da Lei ${ }^{\circ}$ 9.504/97) e na jurisprudência desta Corte - , o que afasta a apontada contrariedade aos arts. $489, \S 1^{\circ}, \mathrm{IV}$, do CPC e 93, IX, da Constituição Federal.

6. O julgado invocado no decisum combatido (Recurso na Rep $\mathrm{n}^{\circ}$ 060051113/DF), a despeito de não cuidar de pedido de registro de candidatura, versou expressamente sobre a impossibilidade de candidatura avulsa, de modo que seus fundamentos, reproduzidos e destacados na decisão combatida, se ajustam, perfeitamente, ao caso em análise.

7. Não há falar em negativa de tratamento isonômico aos postulantes do processo eleitoral, haja vista que, em hipótese semelhante (Pet n⿳0 0600870-60, Rel. Min. Luís Roberto Barroso), a solução adotada pelo relator foi idêntica à conferida no decisum ora agravado.

8. A pendência de julgamento no STF do ARE $n^{\circ} 1.054 .490$ QO/RJ, cuja matéria versa sobre a constitucionalidade da candidatura avulsa, com repercussão geral reconhecida, não atrai, por si só, a aplicação do art. 16-A da Lei das Eleições, pois referida regra pressupõe que o registro de candidatura esteja sub judice, e não que uma questão anterior ao próprio pedido de registro esteja em discussão.

9. As razões postas no agravo regimental não afastam os fundamentos lançados na decisão agravada.

Embargos de declaração julgados prejudicados e agravo regimental desprovido. (grifou-se)

$\mathrm{O}$ argumento principal aduzido a favor das candidaturas avulsas funda-se no fato de que o Brasil é signatário de pactos e convenções internacionais, dentre eles a Convenção Americana de Direitos Humanos (Pacto de San José da Costa Rica). Mais especificamente, o Pacto de San José 
da Costa Rica asseguraria a participação de todos os cidadãos na vida pública, conferindo-lhes o direito de praticar atos de campanha e ter seus nomes inseridos nas urnas eletrônicas.

Dessa forma, as decisões judiciais que indeferiam registros de candidatura avulsa estariam impondo indevidamente restrições relacionadas às condições ao exercício de votar e ser votado, eivadas de ilicitude.

Vejamos o que dispõe a respeito o Pacto de San José da Costa Rica.

O Pacto de San José da Costa Rica (1969), já em seu preâmbulo, estabelece os propósitos do acordo internacional firmado, quais sejam:

a) consolidação no continente americano, no seio das instituições democráticas, um regime de liberdade pessoal e de justiça social, fundado no respeito dos direitos essenciais do homem;

b) proteção internacional, de natureza convencional, coadjuvante ou complementar da que oferece o direito interno dos Estados americanos, em ato de reconhecimento de que os direitos essenciais do homem não derivam do fato de ser ele nacional de determinado Estado, mas sim do fato de ter como fundamento os atributos da pessoa humana;

c) a reafirmação dos princípios consagrados na Carta da Organização dos Estados Americanos, na Declaração Americana dos Direitos e Deveres do Homem e na Declaração Universal dos Direitos do Homem;

d) criação de condições que permitam a cada pessoa gozar dos seus direitos econômicos, sociais e culturais, bem como dos seus direitos civis e políticos, condições reconhecidas pela Declaração Universal dos Direitos do Homem para a realização do ideal do ser humano livre, isento do temor e da miséria; e

e) incorporação à Carta da Organização de normas mais amplas sobre direitos econômicos, sociais e educacionais e resolveu que uma convenção interamericana sobre direitos humanos determinasse a estrutura, competência e processo dos órgãos encarregados dessa matéria.

Dispostos os propósitos da referida convenção internacional, assim dispõe o seu art. 23, ao tratar dos direitos políticos:

1. Todos os cidadãos devem gozar dos seguintes direitos e oportunidades:

a. de participar na direção dos assuntos públicos, diretamente ou por meio de representantes livremente eleitos; 
b. de votar e ser eleitos em eleições periódicas autênticas, realizadas por sufrágio universal e igual e por voto secreto que garanta a livre expressão da vontade dos eleitores; e

c. de ter acesso, em condições gerais de igualdade, às funções públicas de seu país.

2. A lei pode regular o exercício dos direitos e oportunidades a que se refere o inciso anterior, exclusivamente por motivos de idade, nacionalidade, residência, idioma, instrução, capacidade civil ou mental, ou condenação, por juiz competente, em processo penal. (grifou-se)

Assim, os argumentos que militam a favor das candidaturas avulsas defendem, em apertada síntese, que a filiação partidária não se insere dentre as condições de elegibilidade sobre as quais os Estados signatários do Pacto de San José da Costa Rica detêm competência para regular, à luz do art. $23,2$.

A respeito da vigência e aplicabilidade dos tratados internacionais no direito brasileiro, a Constituição Federal estabelece, no art. $5^{\circ}, \S \S 2^{\circ}$ e $3^{\circ}$ :

$\S 2^{\circ}$ Os direitos e garantias expressos nesta Constituição não excluem outros decorrentes do regime e dos princípios por ela adotados, ou dos tratados internacionais em que a República Federativa do Brasil seja parte.

$\S 3^{\circ}$ Os tratados e convenções internacionais sobre direitos humanos que forem aprovados, em cada Casa do Congresso Nacional, em dois turnos, por três quintos dos votos dos respectivos membros, serão equivalentes às emendas constitucionais.

O Pacto de San José da Costa Rica entrou em vigor em 18 de julho de 1978, na forma disposta no artigo 74.2 da Convenção.

O Brasil, por sua vez, aderiu ao referido Pacto em 9 de setembro de 1992, depositando-o em 25 de setembro daquele mesmo ano. Aceitou, ainda, a competência da corte em 10 de dezembro de 1998, nos seguintes termos:

Reconhecimento da competência da Corte

O Governo da República Federativa do Brasil declara que reconhece, por tempo indeterminado, como obrigatória e de pleno direito a competência da Corte Interamericana de Direitos Humanos, em todos os casos relacionados com a interpretação ou aplicação da Convenção Americana sobre Direitos Humanos, em conformidade com o artigo 62, sob reserva de reciprocidade e para fatos posteriores a esta declaração. 
A questão da viabilidade de candidaturas avulsas no Brasil foi elevada à apreciação do Supremo Tribunal Federal e pende de apreciação, em processo com repercussão geral reconhecida (ARE 1054490), que conta com parecer da Procuradoria-Geral da República pela constitucionalidade desse tipo de candidatura.

A ação, cujo relator é o Ministro Luís Roberto Barroso, discute as decisões proferidas pela Justiça Eleitoral nos autos do pedido de registro de candidatura autônoma à prefeitura do Rio de Janeiro, sob o fundamento de que a filiação partidária constituiria condição inafastável de elegibilidade. Encerradas as eleições, o Supremo Tribunal Federal decidiu pela perda do objeto da ação que pleiteava a concessão de tutela provisória, mas reconheceu a repercussão geral, em razão do "processo de objetivação do controle difuso da constitucionalidade" da questão posta à apreciação.

O processo, concluso ao relator, conta com manifestação favorável da Procuradoria Geral da República (ARE 1.054-490-RJ, 2018), cujo excerto constante da manifestação expressamente revela:

O art. 23, inc. 1, b, e o inc. 2, do Pacto de São José veda a restrição da capacidade eleitoral passiva por motivos diversos dos ali estabelecidos, entre os quais não se inclui a filiação partidária, de sorte que o art. $14, \S 3^{\circ}$, da $\mathrm{CR}$ foi por ele privado de eficácia: licitude das candidaturas avulsas no direito brasileiro.

Parecer pelo não conhecimento do recurso extraordinário ou, caso superada a preliminar, por seu provimento (2018).

Observa-se, pois, que a Procuradoria Geral da República se manifestou no sentido da eficácia restrita do art. $14, \S 3^{\circ}$, da Constituição Federal, invalidando o requisito da filiação partidária como condição de elegibilidade.

\section{Conclusão}

O processo eleitoral garante a consolidação da Democracia Representativa. Não se olvide que a legitimidade do poder é fundamental à estrutura da própria Sociedade, cuja organização culmina na concessão do poder institucional a determinado grupo de pessoas que exerce, temporariamente, as funções de governo e de elaboração das leis. 
Denise Goulart Schlickmann \& Orides Mezzaroba

$\mathrm{O}$ acesso ao poder, contudo, não se dá por vontade e disponibilidade exclusivamente individuais, mas mediante a organização partidária, por meio da qual os filiados a determinados grupos políticos consolidados põem-se à disposição de todos para representar os interesses da coletividade e tutelá-los.

Assim, o sistema representativo é expressão de um ato de delegação de poder. E é tão importante para a estruturação da convivência social que as formas de acesso que garantem a condição de um cidadão representar seus iguais é rigidamente regulada no processo legislativo.

Ora, a Democracia Representativa pressupõe o procedimento eleitoral e o próprio sistema eleitoral. Os partidos políticos, nesse viés, são estruturas cuja legislação pátria consagra - ao lado da doutrina até aqui prevalente - como indispensáveis à manifestação da sociedade para consolidação da Democracia Representativa. Apenas mediante a filiação partidária o cidadão pode almejar a candidatura e assim participar da disputa de poder que alcança seu ápice nas eleições.

$\mathrm{O}$ anseio por concorrer ao processo eleitoral com candidaturas avulsas, desvinculadas completamente dos partidos políticos, entretanto, surge no cenário nacional com fundamentos bastante sólidos. Tais fundamentos, que não encontram guarida nas regras nacionais de regência da matéria, estão fortemente alicerçados no direito internacional. As condições de elegibilidade no Brasil, neste momento, estão sendo objeto de profunda discussão no Supremo Tribunal Federal e a filiação partidária - até aqui inquestionável - pode resultar como inexigível.

A complexidade da questão posta irá, ao final, decidir sobre a prevalência da norma internacional, nesse caso limitadora da regra constitucional e da regra ordinária que exigem a filiação partidária como condição de elegibilidade, ou sobre a aplicação da legislação pátria. Qualquer das duas hipóteses aponta à necessidade de fortalecimento das estruturas partidárias, quer pela sua indispensabilidade, quer por passarem a representar uma opção ao candidato para alçar o poder político constituído.

\section{REFERÊNCIAS}

AIETA, Vânia Siciliano. Partidos políticos. Rio de Janeiro : Lumen Juris, 2006. 342 p. 
BRASIL. Constituição da República Federativa do Brasil - 1988. Diário Oficial da República Federativa do Brasil, Brasília, DF, 5 out. 1988. Seção 1, p. 1.

. Lei $n^{\circ}$ 9.504, de 30 de setembro de 1997. Estabelece normas para as eleições. Diário Oficial da República Federativa do Brasil, Brasília, DF, 1 out. 1997. Seção 1, p. 21.801.

. Lei $\mathrm{n}^{\circ} 13.488$, de 6 de outubro de 2017. Altera as Leis $\mathrm{n}^{\circ} \mathrm{s} 9.504$, de 30 de setembro de 1997 (Lei das Eleições), 9.096, de 19 de setembro de 1995, e 4.737, de 15 de julho de 1965 (Código Eleitoral), e revoga dispositivos da Lei $\mathrm{n}^{\mathrm{o}}$ 13.165, de 29 de setembro de 2015 (Minirreforma Eleitoral de 2015), com o fim de promover reforma no ordenamento político-eleitoral. Diário Oficial da União, Brasília, DF, 6 out. 2017. Edição extra. Seção 1, p. 1.

. Tribunal Superior Eleitoral. Agravo Regimental em Petição nº 600614-20.2018.6.00.0000.

Relator Min. Tarcisio Vieira De Carvalho Neto. Publicado em Sessão, Brasília, DF, 20 nov. 2018. . Supremo Tribunal Federal. Recurso Extraordinário com Agravo n 1054490/RJ.

Disponível

em:

$<$ http://www.stf.jus.br/portal/jurisprudenciaRepercussao/verAndamentoProcesso.asp?incidente=5 208032\&numeroProcesso=1054490\&classeProcesso=ARE\&numeroTema=974>. Acesso em: 31 mar. 2019.

BOBBIO, Norberto. Teoria geral da política: a filosofia política e as lições dos clássicos. Rio de Janeiro : Campus, 2000. 717 p.

BONAVIDES, Paulo. Curso de direito constitucional. 5. ed. São Paulo: Malheiros, 1994. 503 p. CADEMARTORI, Luiz Henrique Urquhart; DUARTE, Francisco Carlos. Estado de direito no contexto do neo-constitucionalismo e o papel das garantias fundamentais. CONPEDI, 2006, Manaus. ANAIS ... Manaus: CONPEDI, 2006.

CAMPOS NETO, Raymundo. A democracia interna nos partidos políticos brasileiros. Belo Horizonte : Editora D’Plácido, 2017. 186 p.

CANOTILHO, José Joaquim Gomes. Direito constitucional e teoria da constituição. 7. ed. Coimbra : Edições Almedina, 1991. 1.522 p.

CAVAlCANTI, Themistocles Brandão. Teoria do Estado. 2. ed. Rio de Janeiro: Borsoi, 1969. $468 \mathrm{p}$.

DUVERGER, Maurice. Os partidos políticos. 3 ed. Rio de Janeiro : Guanabara, 1987. 465 p. 
Denise Goulart Schlickmann \& Orides Mezzaroba

FERRAJOLI, Luigi. A democracia através dos direitos. São Paulo: Editora Revista dos Tribunais, 2015. $254 \mathrm{p}$.

GOMES, José Jairo. Direito eleitoral. 13. ed. São Paulo : Atlas, 2017. 914 p.

KELSEN, Hans. A democracia. São Paulo : Martins Fontes, 1993. 329 p.

. Teoria pura do direito: introdução à problemática científica do direito. Tradução de

J. Cretella Jr. e Agnes Cretella. São Paulo : Editora Revista dos Tribunais, 2001. 159 p.

LOPES, Nei. Inelegibilidade no Brasil. In: Revista brasileira de direito eleitoral. Fortaleza, p. 1927, jul./1990.

LÓPES, Mario Justo. Partidos políticos. Teoria general y regime legal. 3. ed. Buenos Aires : Depalma, 1982. 169 p.

MACHADO, Raquel Cavalcanti Ramos. Direito eleitoral. São Paulo : Atlas, 2016. 295 p.

MEZZAROBA, Orides. Partidos políticos. Curitiba : Juruá, 2005. 192 p.

. Introdução ao direito partidário brasileiro. 2 ed. Rio de Janeiro : Lumen Juris, 2004. p. 347.

OPPO, Anna. Partidos políticos. In: BOBBIO, Norberto; MATTEUCCI, Nicola; PASQUINO, Gianfranco. Dicionário de política. Tradução de VARRIALE C. et al. 11. ed. Brasília : Editora Universidade de Brasília, 1998.

ORGANIZAÇÃO DOS ESTADOS AMERICANOS. Convenção americana de direitos humanos (Pacto de San José de Costa Rica). Disponível em: $<\mathrm{https}$ ://www.cidh.oas.org/basicos/portugues/c.convencao_americana.htm>. Acesso em $31 \mathrm{mar}$. 2019.

RIBEIRO, Telmo Vieira. Democracia, solidariedade do agrupamento social. In: OLIVO, Luis Carlos Cancellier; PASOLD, Cesar Luiz (Org.). Duas teses de Telmo Vieira. Joaçaba : Editora UNOESC, 2015. $205 \mathrm{p}$.

SILVA, José Afonso da. Curso de direito constitucional positivo. 10. ed. São Paulo: Malheiros, 2000. $871 \mathrm{p}$. 